http://artnodes.uoc.edu

ARTICLE

NODE: «ART MATTERS»

\title{
Net-garden: Art, Nature \& Society or the Need for a Relational Vision of Organic and Social Life*
}

\author{
Lorena Lozano \\ Artist and biologist \\ Oviedo University (Asturias) \\ Submission date: April 2015 \\ Accepted date: April 2015 \\ Published in: June 2015
}

\begin{abstract}
As an analytical and critical framework, this text reviews some perspectives for understanding the natural-life-organic processes connected to traditional science and art praxis in recent decades. Among them, the historical dimensions of scientific and artistic discourse, the positions of ecology, social movements and some of the key ideas around the aesthetics of nature and bio-politics. The implementation of two strongly empirical artistic projects as research (ecoLAB and Herbarium) raised a few questions relating to the metaphysical articulation of nature's concept, meaning and relationship with society and art: How do the new modes of biotechnological manipulation detach the capacity for production and reproduction from the communities (human-non human) in which they are historically immersed? How can trans-disciplinary artistic approaches contribute to generating new ways of living and coexisting? How do they influence art praxis? How do art matters regarding the ecological turn towards slow science and slow art? The projects presented arise from a position of questioning the classic Western dichotomy between nature and culture, and the technological realm in relation to the knowledge, production and reproduction of organic and social processes. The
\end{abstract}

\footnotetext{
* This article is part of my PhD research project developed over the last four years. The thesis project is a trans-disciplinary study that arises from a series of questions about how the discourses of art and science produce knowledge and public stories regarding nature. The study investigates the dialectical relationships of contemporary art in the mediation and social perception of nature. It follows a qualitative research methodology based on anthropology, sociology of science and artistic practice. In December 2014, I presented a paper at Art Matters International Conference that described the theoretical framework of my research and presented two artistic projects I have developed as artist and researcher. These projects were fieldwork and epistemic objects of study in the first stages of my research. The conclusions of the paper are briefly discussed in this article.
} 


\section{artnodes}

http://artnodes.uoc.edu

Net-garden: Art, Nature \& Society...

projects are case studies and fieldwork for research, informing and also testing new ways of understanding the human-biosphere nexus. The evaluation process shows strategies of cultural representation and relations, linked to today's environmental reality and virtuality. In the current social context characterised by knowledge and life economies, they work on the need to cultivate the appropriated technological aptitudes and to consider the potentialities of human and non-human agency. They construct ways of preserving and managing the commons, and reveal themselves in local, everyday practice and in the construction of the landscape, its perception and experience.

\section{Keywords}

nature, environmental aesthetics, naturpolitik, slow science \& art, commons, self-organisation

\section{Jardín en red: arte, naturaleza y sociedad o la necesidad} de una visión relacional entre la vida orgánica y social

\section{Resumen}

Este artículo, como marco de análisis y crítica, revisa algunas de las perspectivas para comprender los procesos de la vida natural y orgánica en relación con las prácticas tradicionales científicas y artísticas en las últimas décadas. Algunas de dichas perspectivas son las dimensiones históricas del discurso científico y artístico, las posiciones de la ecología, los movimientos sociales y algunas de las ideas claves en torno a la estética de la naturaleza y la biopolítica. La implementación de dos proyectos artísticos marcadamente empíricos como investigaciones (ecoLAB y Herbarium) planteó algunas preguntas en relación con la articulación metafísica del concepto, el significado y la relación de la naturaleza con la sociedad y el arte: ¿Cómo separan las nuevas formas de manipulación biotecnológica la capacidad de producción y reproducción de las comunidades (humanas-no humanas) en las que estan históricamente inmersas? ¿Cómo pueden contribuir los planteamientos artísticos transdisciplinarios a generar nuevas formas de vivir y coexistir? ¿Cómo influye en la práctica artística? ¿Qué importancia tiene el arte con respecto al giro ecológico hacia una ciencia y un arte lentos? Los proyectos presentados surgen a partir del cuestionamiento de la clásica dicotomía occidental entre naturaleza y cultura, y del reino tecnológico en relación al conocimiento, así como la producción y reproducción de procesos orgánicos y sociales. Los proyectos son estudios de caso y trabajos de campo para la investigación, que, además de probar nuevas formas de entender el nexo humano-biosfera, informan sobre ellas. El proceso de evaluación muestra estrategias de representación y relaciones culturales, vinculadas a la realidad y la virtualidad medioambiental actual. En el contexto social actual caracterizado por las economías del conocimiento y la vida, estos proyectos se centran en la necesidad de cultivar las aptitudes tecnológicas adecuadas y en considerar las potencialidades de la agencia humana y no humana. Construyen formas de conservar y gestionar lo común, desvelándose en la práctica local y cotidiana y en la construcción del paisaje, su percepción y experiencia.

\section{Palabras clave}

naturaleza, estética medioambiental, naturpolitik, ciencia \& arte lentos, bienes comunes, autoorganización 


\section{artnodes}

\section{Ecological crisis, social movements and ways of thinking in recent decades}

The so-called ecological crisis started to become a key concept in relation to the energy crisis in the 70 s along with the rise of the world's population. The emergence of this ecological crisis put an end to the industrial society's illusion of technological development as a solution for the scarcity of resources and natural catastrophes (García 2004, pp. 59-100). In an attempt to reformulate developmental theories, the concepts of ecological modernisation and sustainable development appeared, both focused on the research and value of technological risks, environmental politics and economy. However, the reality is that the ecological crisis is also a huge social conflict that manifests itself through the different forms of access to resources and to the scope of risks. Moreover, the conceptualisation of sustainability is based on ecological, social and economic dimensions and researchers have only recently started to study its theoretical core, values, attitudes, behaviours and environmentalist movements (Redclift and Woodgate, 1997).

As a result of the social actions of certain agents regarding environmental issues since the end of 60's, mainly in northern Europe and the USA, a whole series of collective and multifaceted behaviours known as environmentalism or ecologist movements (Castells 2002, pp. 135-158 and 2009, pp. 393-533) emerged. The author argues that they have been, and still are, the social movement with greatest impact on current lifestyles and on collective ways of thinking in relation to nature. The science of ecology, as a sociological, holistic, integrative and evolutionary approach, and the systemic way of thinking and observation, are the key theoretical and methodological instruments of this movement. The change it proposes concerns conscience and politics, affecting the ideas of time and space and the notion of limits in our society. It proposes the "historical redefinition of space-time and the inter-generational solidarity under a-historic time concept" (Castells, 2002, p. 150). Its actions are decentralised and articulated as networks, with a local vision in relation to space and community, and a global vision in terms of time, thought and politics. During the three decades of re-programming communication networks, the long march of environmentalism, as Castells called it, has adapted to the mass media, translating scientific language to the general public (Castells, 2009, p. 414). Its code of communication is based on restoring confidence and highlighting ethical and humanistic values through non-violent direct action, often of a strong performative nature, and references to health, citizenship participation and violation of environmental laws. In contrast to the dominant structural and institutional logic, its objectives, discourse and practice aim to mend the destructive relationship between human action and the natural environment (Castells, 2002, pp.135-158). It seeks to promote a change of attitude at the level of technological development, the market, sustainable democracy, decentralisation and the accumulation of capital, and also questions reproductive behaviour, the meaning of ageing and death, etc. Its effects and scope have influenced urban planning projects in cooperation with local agents, and have sometimes become political and turned into indicators of public health and control of urban and industrial development. However, the supremacy of urbanity over rurality and the relocation of international corporative exploitation sites and productive processes are huge obstacles. According to Latour (2013), the stagnation of green movements is due to an approach to nature as an aesthetic object, subject to rights. He argues that nature stopped being a mode of political organisation as it used to be in classical Greece, when it was present in every discussion to change or reform public life and where people never talked about politics without talking about nature. For decades, the objective of green movements has been to direct the politics of nature towards modifying public life, in order to take nature into account, and to try to give nature a role in public life, which has hindered their convergence with political movements (Latour, 2013, pp. 29-96).

On the other hand, despite the proliferation of many new paradigms laid out by social movements, among researchers and intellectuals who explore the challenges of the current network society faced with ecological crisis in Western culture, the idea of discontinuity in the nature-society relationship is widely extended. Hence, many of these new paradigms and ideas are still fragmented today. The environmental movement includes a huge variety of voices, of which the prevailing ones are deep ecology, born in Scandinavian countries, and earth ethics, born in North America; both of these propose a bio-sphere egalitarianism or biocentric perspective, and the more recent new animism and dialectical realism. In the field of philosophy, the Frankfurt school generated an ideology-politics of nature whose premise is "nature as a source of freedom and creativity when humans are in aesthetic and egalitarian relation to nature" (Martínez Rivillas, 2012, pp. 292-293). These ideas give rise to positions, such as ecocriticism and eco-feminism, which are based on various different cosmos-visions and cultures. It challenges life sustainability and relies on the idea of transforming the patriarchal system through the parallelism between the control of women and the exploitation of nature (Guerra Palmero, 2004, pp. 227-233). Regardless of this plurality of voices and although in the current context identity is "subject to global and very abstract fluxes of wealth, power and information", this movement "has a collective biological identity, an identity as species, that seeks to eliminate historical gender, social and religious bonds" (Castells, 2002, p. 147-152).

Furthermore, the ecological crisis and social conflicts of the late 60 s caused a division in different disciplines, including the disciplines of chaos and complexity, in which Morin (1998) and others interpreted phenomena from multiple perspectives, setting up common, multidimensional patterns consistent with the complexity of social reality. This multi-disciplinary view and the changes of paradigm 


\section{artnodes}

reformulated the epistemology around the social construction of knowledge and environmental intervention itself, building bridges between quantitative and qualitative methodologies in sociology and other sciences (Martínez Rivillas, 2012, pp. 292-293). This led to the emergence of concepts derived from ecology, such as healthy ecology, by Bateson (1972), social ecology, by Bookchin (1982), and the sociological model of nature-society interaction based on the idea of co-evolution by Norgaard (1994 in García, 2004, p. 31). From the perspective of post-modernity, the characterisation of environmental, social and mental ecologies and the conceptualisation of the ecosophy by Guattari (1989), together with Deleuze (1980), replaced tree-like hierarchical social organisation with a rhizome-like growth pattern. These ideas have widely influenced psychoanalysis, philosophy, aesthetics and the arts. Michel Foucault's (1976) idea of biopower or power over life opens up a debate around the political formation of life technologies. In this sense, Haraway (1991, p. 46) reasserts a historical explanation based on reproduction and considers "nature as a capitalist market scientifically managed", while proposing the metaphor of the cyborg-an organism-machine hybrid that addresses transgender boundaries and fusions between nature and culture. The so-called ecological, sanitary or economical crisis is theorised as a crisis of perception and cognition by Giobellina (2012, p. 1-17), who argues that there is a need for new institutional forms of participation, representation and knowledge production based on intra-generational and intergenerational processes and taking into account common goods. Others such as Escobar (1999, pp. 1-30), suggest that there is a crisis of identity of nature itself, and argue for the need for a relational vision of organic life with social life, while Latour (2013, pp. 29-96) posits a crisis of objectivity that places the question of scientific production at the heart of political ecology.

\section{Natural history, artistic discourse and environmental aesthetics}

Looking at the connection between art and nature from the perspective of aesthetics, artists painters, sculptors, musicians and filmmakers have historically represented the feelings and meanings triggered by nature in a very wide range of ways. When talking about the aesthetics of nature the term landscape is often used. The origin of the concept is historically situated in Europe and has many connotations related to art history, but also to the political, social and cultural context. This political relationship is expressed in many pictorial representations and, as Rolston (2002, p. 140) writes, "looking to natural history and how humans place themselves in those landscapes, it is also possible to appreciate how aesthetics comes out again and again". In this historical dimension, natural history or the history of natural sciences, from the classical world until today, has included a recurrent idea: Plinio's Scala naturae, in which all organisms can be ordered in a linear continuum, starting with the most simplest life form and working up to the most complex, usually human beings. This hierarchy is maintained in the exploitation of resources during colonial times, in the enclosure of common lands and during the reproductive control carried out by the witch hunt in Medieval Europe, when new ways of plant, animal, and human control made the earliest ways of economic globalisation possible. In the eighteenth century, the Linnaean system for the classification of plants (1735), based on sexual characteristics as adaptive elements in evolution, and, Darwin's idea of natural selection (1859) in the nineteenth century reaffirmed a certain biological determinism in social organisation. In the field of the arts, the philosophy of the Tuscan Humanists in the Renaissance entailed a turning point in the way of looking at nature, very clear in many artistic expressions, which reveal an observation of nature that goes beyond aesthetic questions and touches on the birth of empirical science (Pächt, 2011). The construction of the polders for pastures in Holland transformed the country into a place of abundance, so that the lantscap or landscape brought about a sort of social utopia (Luginbül, 2008, p. 157). Linear perspective enabled the sensation of freezing the depicted place and time, situating the observer in an external position, outside of history and of nature (Escobar, 1999, p. 6). The industrial revolution transformed the political, social and economic context, and the landscape phenomenon became a cultural matter, in the sense of what marks the historical core of natural beauty (Adorno, 2004, pp. 87-108). "With the art of landscape, nature took a passive role, without power of agency" (Escobar, 1999, p. 6), and its aesthetic categories were based on an idea of beauty related to the picturesque and sublime, archetypes of the natural and the wild, expressed in landscape models from the English garden (Luginbühl, 2008, p. 156). These ideas shaped certain stereotypes of nature that remain to this day, such as the widespread concepts of landscape scenery and mother earth, with a historical dimension reflected in aesthetic theory and art history. The mass media now exert an immense power over those stereotypes in regard to nature, which tend to be accepted without critical analysis, leading to a general reductionist and erroneous consensus. They are often converted into metaphors that have an echo in the collective imaginary. In general, the concept of nature relates to naturalistic ideologies shaped historically, which legitimatises the goodness of a product, an institution or idea, formal or rhetorically binding them to an assumed law or natural model, "an idea of nature as moral principle, that legitimises anything related to it and, as metaphysical concept, related to something that is being destroyed and can be saved as a means of certain attitudes or consumption of specific products" (Albelda and Saborit, 2004, p. 225).

In this overview of the history of natural sciences and art history, we can see that conservationism, scientific cognitivism, aesthetic appreciation and the aesthetics of compromise are closely connected 


\section{artnodes}

http://artnodes.uoc.edu

Net-garden: Art, Nature \& Society...

(Rolston, 2002, p.140). However, in terms of conservation and resource management, the aesthetics of nature have historically been much more important than environmental aesthetics. According to Izaguirre (2010, p. 16-26), it is precisely this identification between nature aesthetics = art theory, that often leads us to value nature in aesthetic terms. From the perspective of environmentalists, the historical aesthetic approaches to nature are anthropocentric visions, obsessed with scenery, superficial, subjective and morally empty. These opinions are forged even as ethical obligations to maintain healthy ecosystems and environments are not accomplished (Carlson, 2009 , p. 7). The work of activists, environmentalists and socially committed artists generates a sort of landscaping utopia (Luginbül, 2008, p. 161), which is expressed in the so-called environmental aesthetics linked to the ethics of nature. As an alternative to the classic paradigm of landscape, environmental aesthetics opens up a plurality of landscapes (Izaguirre, 2010).

Since the beginning of the 20th century, avant-garde artistic production has also worked towards the creation of new imaginaries in relation to nature that go beyond representations and landscape images. Moreover, in parallel to the environmental movements and the ecological turn in society, contemporary artists have been producing images, representations and projects that address questions about biodiversity, science and ecology in connection to social change. The most influential example emerged in the 70s with the theory and practice of social sculpture by Beuys, which was mainly based on political implications and environmental concerns. Beuys understanding of art is based on the idea of evolution from an isolated practice of art to the configuration of a wider concept that opens up the horizon of creativity beyond the art ghetto, approaching the needs of human beings. Historically, artistically immanent stylistic innovations have been the concern of art, but according to Beuys, the prevailing idea now is linked to the involvement of the social body as a whole, to opening up an amplified conception of aesthetics, through art. In the USA, the same decades were marked by the opening of the Exploratorium, the first museum of science, art, and human perception located in San Francisco, and by the emergence of art practices linked to ideas such as the move towards sustainable art, art, ecology, the politics of change and cultural ecology. Among other examples, the interdisciplinary group Pulsa created the Harmony Ranch project, an experiment based on communal cohabitation, self-sufficient agriculture, collaborative art and music projects. Their intention was to break down the separation between the natural and the social, the political and the technological (Demos, 2009, pp. 17-30). During the 80 s and 90 s, other practices emerged as an alternative to institutional public programmes, creating a new scene of social organisation in which local actions started to connect to global actions and proposing alternatives to change. Group Material in New York defended that artists can actively collaborate with citizens in the construction of participative spaces, transgressing the public realm and looking for a shared interest. At the end of 20th century, Bourriaud (2002) proposed the possibility of a relational art that takes as its theoretical horizon the sphere of human relations and its own social context, rather than an independent, private symbolic space (Bouriaud, 2002, pp. 11-17). He proposed the collective construction of meaning through a system of intensive encounters linked to artistic practice. Nowadays, the use of digital technologies and telecommunication generates new dimensions and a wide rapport with the arts. New communication technologies also affect the basic premises of artistic praxis, as well as the aesthetic discourse and the socio-cultural structure. Some contemporary artistic expressions establish close connections between art and science, and categories such as bio-art and generative art are widespread today. Political art trends, new forms of virtual communication and the confluence with environmentalist movements enable issues such as the environment and ecology to become a powerful instrument in artistic contemporary culture. Many practices and projects address topics related to biotechnology, while others stem from the hybridisation of practices that use new and emerging green spaces in the cities as their testing ground or re-appropriate rural spaces for a range of purposes. At the same time, artists play the role of creators, social mediators, researchers and knowledge producers. Some initiatives try to show the division between the socio-technological system and the biopolitical system, and "in many cases the intention is to transcend the political functionality of human experience and the des-idealisation of nature" (Demos, 2009, p. 23).

\section{Two empirical artistic projects as research}

ecoLAB and Herbarium are two collaborative artistic practice projects that work on new ways of understanding and interrelating the humanbiosphere nexus.

3.1. ecoLAB (2011-2012, LABoral Centro de Arte y Creación Industrial, Gijón, Asturias, Spain, is "an experimentation laboratory at the intersection between ecology, art and open electronics". It aims to generate subjectivities and dynamics in relation to the biosphere and its ecosystems, through the creation of new forms of representation and the implementation of eco-technologies (hightech and low-tech). LABoral Centro de Arte is located in a small

1. My role as co-founder and coordinator of ecoLAB and author and artistic director of Herbarium, have allowed me to define the lines of research and document the processes very closely. 


\section{artnodes}

regional city on the north coast of Spain, where, as in many other parts of the Atlantic area, there has traditionally been a very close connection between urban and rural zones. The last 150 years of industrialisation entailed a difficult transition from a post-industrial and agrarian society to a metropolitan, computerised society. Against this backdrop, the project was based on an applied observation of space and on bioregionalism, seeking forms of development that prioritise and adapt to local communities with specific interests in sustainability and durability. Over a period of two years, funded mostly by Gijón City Council, it was transversally embedded in LABoral art centre. During this time, it was organised as an emergent project run by artists who transmitted a sense of re-appropriation of the space, combining community aims with network-building. They organised activities, public encounters and scientific debates in which to produce sound, visual images and electronic devices to name a few examples. The southern courtyard of the LABoral building was the hub for meeting and experimentation, and the artists collaborated on monitoring and maintaining the garden's biodiversity through a set of networked sensors and through the development of urban agriculture models based on traditional architecture. In parallel to the encounters, the participants set up and re-enforced a local, national and international network of creators and artist with similar interests, which still operates today under the name of econodos (ecology \& communication). ecoLAB's location and the difficulty of transmitting new imaginaries and ways of working with nature evoked the medieval idea of the garden as a hortus conclusus. From the inside, the surrounding physical context is imperceptible. It suggests a similar approach to the lifestyle of erudite abbots, jealous guardians of their wisdom, who seek functionality and recreation in their enclosed garden so that -despite the vast knowledge of natural resources and agronomy- it becomes an overlapping universe (Lozano, 2014).

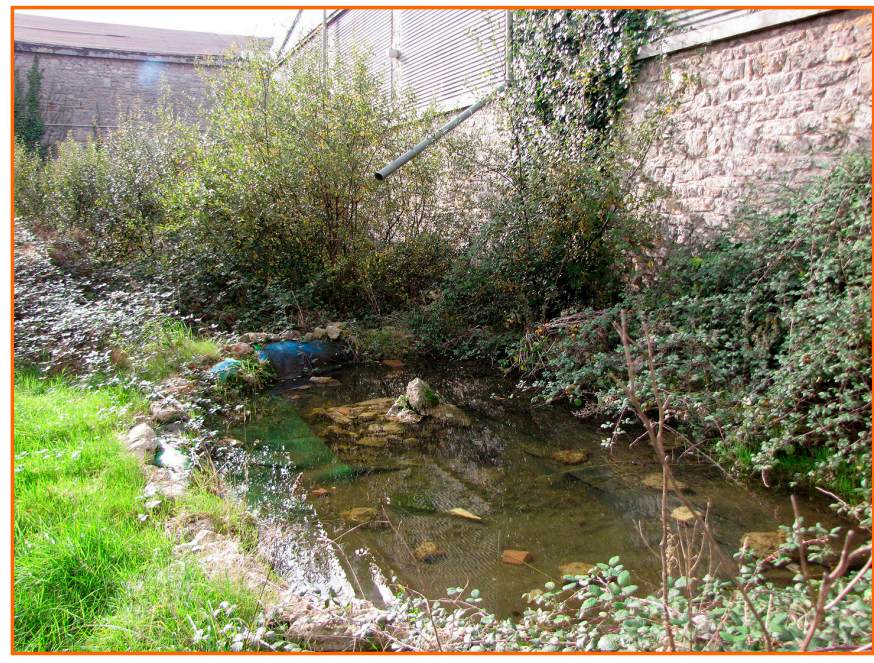

Caption image 1: The pond at ecoLAB's southern courtyard (2014)
To this end, taking into account the preceding review of the historical dimensions of scientific and artistic discourses that draw from the positions of ecology, social movements and some of the key concepts of the aesthetics of nature and biopolitics, ecoLAB posed a series of questions: How do the new modes of biotechnological manipulation remove the capacity for production and reproduction from the communities (human non-human) in which they are historically immersed? How can trans-disciplinary artistic approaches contribute to generating new ways of living and co-existing?

\subsection{Herbarium}

The controversial local-global and human-biosphere relationships were addressed differently by the project Herbarium (2013-ongoing Fundación Cerezales Antonino y Cinia, FCAYC, León). This project was born as an attempt to explore the question of the local in relation to nature within the particular field of the history of plants, art and the convergence between science and popular knowledge. Since 2013, it has been developed in a historical rural context of the Castilian countryside, mainly through the ethno-education framework of FCAYC. The project consists of encounters with local groups of different ages, focusing on the re-interpretation of local flora, knowledge exchange and the redefinition of the landscape. The project is strongly itinerant in nature, given that the processes can be replicated under the same methodologies and that some sessions are occasionally organised in other rural areas. Some of the activities implemented during the encounters are exploration of the nearby environment, compilation of dry plants and a series of art and science workshops. The processes are documented audio-visually and archived in a database providing public access, which is slowly becoming a tool and a virtual space for the learning of biology and life discourses. In the current scenario of generational dilemma, it boosts the transmission of knowledge and establishes a dialogue between contemporary creation, landscape, identity and territory. It approaches the ethnographic domains of popular culture in relation to science and technology, the popular imaginary and digital literacy. The project is essentially based on an anthropological and experimental approach in which vegetables or organic nature, given their social and historical implications, are considered as political agents. The methodology allows for a long-term relationship with place and community and makes it possible to observe the territory according to its bio-geographical, historical and socio-cultural dimensions, as well as to explore the city-countryside relationship, the social perception of the landscape and attitudes to environment. It explores how the community reveals the relation between the human and biological worlds and their distinctions and classifications of the biological realm (Escobar, 1999 pp. 1-30). Metaphorically it is constructed as a map of connections between inhabitants and landscape, approaching memory from the perspective of the natural elements that consolidate the territory. 


\section{artnodes}

http://artnodes.uoc.edu

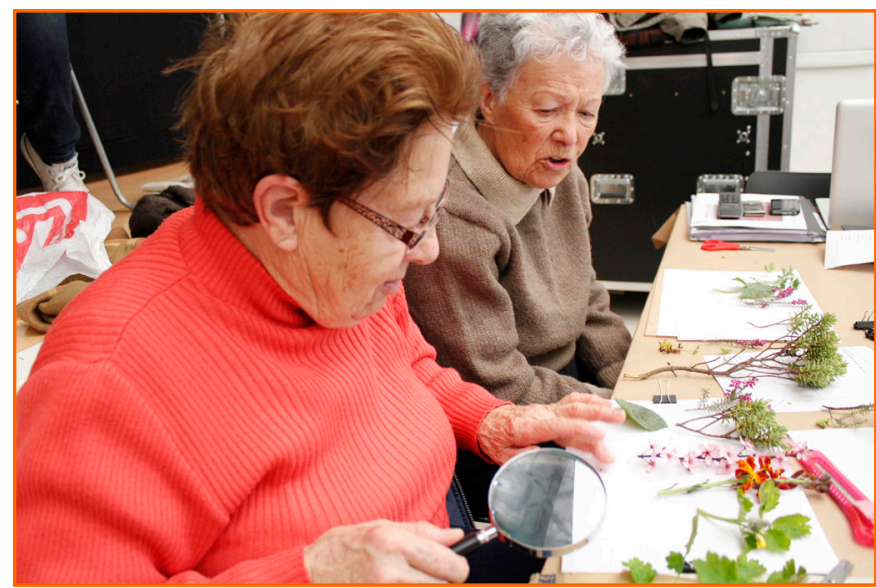

Caption image 2: Image of processes during Herbarium. Photo by Fundación Cerezales Antonino y Cinia (2013)

\section{Naturpolitik: the need for a relational vision of organic and social life}

Science and technology shape the explanations, models, attitudes and perceptions through which we look at and understand nature. However, the critique of science and technology could be ambiguous and deep, given that they are also the foundations of knowledge, and the means and objectives of the economy and society in general. On the other hand, the solution to environmental problems requires the transformation of modes of production and consumption, but also of the personal lifestyles and forms of social organisation. Moreover, the relationship between the environment and society is two-way: social issues make transformations in natural environments possible, and they have an effect on environmental transformations and changes. These relationships are established in socio-historical systems and integrated within evolutionary-biological environments, which "involve a mismatch, due to the fact that society responds to a cultural evolution, while ecosystems respond to a biological one" (García, 2004, p. 23). This mismatch can be seen in the question of biodiversity. The capacity for production and reproduction of human and non-human communities is regulated by a large variety of forms of biotechnological manipulation. The largest wealth of biodiversity today is located in scientific laboratories and in rural territories, while the economies of knowledge -and the economies of life and natural resources-are shaping the landscape of the new information society. The concepts of biodiversity and sustainability are bound to ecological and economic aspects, which are also considered key factors for increasing the physical wellbeing of human beings. Biodiversity refers to the degrees of variation of life forms and the genetic heritage of a given species, ecosystem, biome or planet, while, paradoxically, sustainability is about the intelligent, efficient exploitation of natural
Net-garden: Art, Nature \& Society... resources, many of which are part of that biodiversity. Both the preservation and measurement of biodiversity and the exploitation of natural resources take place through science and its progeny -technology. However this techno-science perspective is not an absolute understanding of biodiversity, sustainability, landscape or nature. In this sense, Escobar (1999, p. 6) suggests that we study nature from the perspective of three regimes: organic nature through the anthropology of local knowledge, capitalist nature in terms of historical materialism and techno-nature from the perspective of science and technology studies. In any case, organic nature, or biodiversity as such, encompasses local knowledge, integrating cultural biodiversity and the cultural expressions linked to a particular ecosystem. This knowledge diversity is something that humans have developed through history based on their close relationship to biodiversity. It includes beliefs, myths, dreams, legends, language and psychological attitudes; in other words, the management, exploitation, enjoyment and understanding of the natural environment. This term helps us to understand biological evolution taking into account all aspects of human intervention, in social production and in social reproduction.

This opens up more questions: Does techno-nature enable a new experience that promotes a different continuity between the social and the natural? How does it influence the art praxis? How do art matters in regard to the ecological lead towards slow science and slow art?

In this sense, Latour (2013, p. 29-96) affirms that in Western culture today, the difficulty of positioning organic-technological hybrids within a classical hierarchical organisation of living beings, it is a clear expression of the assumption of nature as a vast political scenography and a moral question. In the face of the contradictions between scientific facts and aesthetic values (moral o political), he proposes the practice of a political ecology that helps by placing scientific production at the heart of ecology and environmental and biological problems. On the other side, in order to understand the forces that link social change, the environment, and development, Escobar (1999, p. 1-30) suggests mixing the modern with the traditional, and the local with the transnational to create fusions that enable the creation of hybrid social realities and cultural practices, which are often embedded in collective identities with organic-artificial components. He proposes a political ecology in which social and biological perspectives are central but not essential, and he suggests looking at the discourses and life practices through which biology has been introduced in history, affirming that "organic forms document artificial processes and nature is no longer in relation to humans; the biological becomes a question of design, creating radical biological otherness" (Escobar, 1999, p. 11). In his opinion, the current breakup of the meaning of the natural realm, opens up many possibilities that can take us to a new art of living in society/nature. He also points out the importance of taking into account the position within the current circuits of power and knowledge, and the apparatus of biodiversity 


\section{artnodes}

http://artnodes.uoc.edu

Net-garden: Art, Nature \& Society...

production. His proposed analytical framework of the three regimes of nature is based on the reconstruction of nature as a condition for potential sustainable development and the re-appropriation of hybrid natures.

In line with those ideas of political ecology, the art projects discussed in this paper refer to the technological realm in relation to knowledge construction, production and reproduction of organic and social processes. Within electronic cyberspace and the materialspatial context, they re-structure an imaginary with possibilities for new hybrids and for promoting transversal, collective identities. This is manifested on the production of ecoLAB new biosphere sonic and visual narratives and Herbarium database. The conventional definitions of city and countryside are challenged through both projects through the intervention in peri-urban and rural territories. The implications of the re-construction of place are based on environmental identification and participation processes such as the transformation of the southern courtyard in an unconventional non-garden by ecoLAB and the convergence between science and popular knowledge in Herbarium. They show that the city and the urban environment are no longer the only realms in which the most relevant artistic expressions are being developed. They also reveal the need for cultural policies regarding sustainability that reconstruct ways of preserving and managing the commons.

Just as biodiversity does not refer only to organic nature, but necessarily includes cultural biodiversity, "sustainability does not only refer to the exploitation of natural resources, it also refers to the ability to adapt to change, which is a skill that characterises artists in the multifaceted uncertainty of the knowledge economy" (Letowska, 2009). ecoLAB re-appropriation of space within an art centre and the itinerancy of Herbarium are examples of this adaptation. They set in motion a whole series of alternative cultural practices that create a bond between the art world and the socio-political reality, defining strategies of cultural representations and relationships linked to the current environmental reality and virtuality. ecoLAB local, national and international network and the circulation of new city-countryside relationships in Herbarium, facilitate the link of local and global actions allowing the exchange of knowledge, ideas and methodologies while establishing dialogues and re-interpretations of traditional technologies in addition to the new information and digital tools. The scenario, in the form of a relational, complex processes-construct, weaves a netgarden - a socio-political space of self-organisation sustained in the context of the global society.

These artistic initiatives are born from the symbiosis between artists, activists and artistic or cultural institutions setting in motion laboratories, learning environments, knowledge archives and temporary autonomous zones (Bello, 2013): processes, experiences, forms of knowledge and values that contextualise research and extrapolate the studies to a broader world, outside of traditional research. Methodologically, the documentation and archiving of processes in both projects creates new virtual spaces for biology and life discourses and opens up possibilities for qualitative research. They open up new forms of knowledge production by working on the recuperation and visualisation of hidden ecological structures. It can perhaps be seen as the cultivation of what Bennett (2010) describes as a green materialism, in which the agency of a vital materiality or vibrant matter -inherent to all material forms- has political implications that are revealed through the physical phenomenology of common things. This is to discern the network of forces that affect situations and consider the active participation of human and non-human forces in social events (Bennett, 2010, pp. 94-109). As a whole, they generate models of appreciation-perception, recovering what Stangers (2011) calls slow science. Artistic practice and scientific research establish bridges and introduce new epistemic objects of study, while art projects are designed as case studies, research briefs and fieldwork for scientific research. They play a key role in the generation of subjectivities and aesthetic experiences, as much as in the understanding of the natural environment and the need to cultivate the appropriate technological attitudes. Both projects practice Naturpolitik ${ }^{2}$ as a dialogue of ecological scope, philosophy and movement of public affairs and private life, a search for a more relational vision between the organic and social life. They endorse a tissue of alternative instituent cultures and economy networks, reaffirming nature as something that is essential to human experience.

\section{Art Matters ${ }^{3}$ \\ No Matter, Never Mind \\ No matter, no life}

2. The expresion Naturpolitik is a term used by Latour (2013, p. 43) refering to the environmental movements theory detached from their philosophy.

3. Inspired by the poem "No Matter, Never Mind" by G. Snyder (1974). 


\section{artnodes}

http://artnodes.uoc.edu

Net-garden: Art, Nature \& Society...

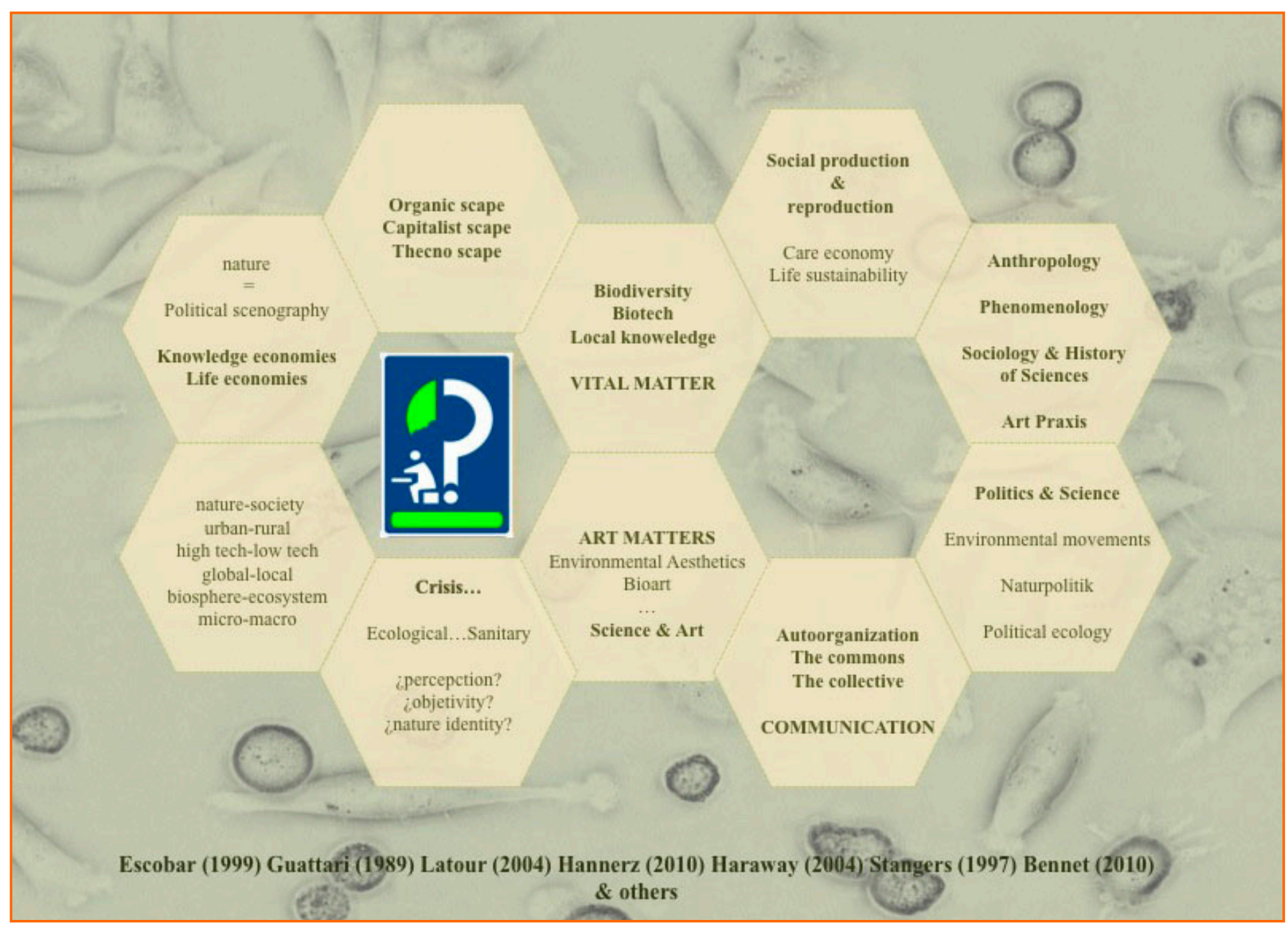

Caption image 3: Net-garden conceptual map by Lorena Lozano (2014)

\section{Bibliographical references}

ADORNO, T. (2005). "La Belleza Natural”. Teoría Estética. Madrid: Ediciones AKAL, pp. 87-108. (1st ed. 1970).

ALBELDA, J.; SABORIT, J. (2004). "Estereotipos de la naturaleza en la iconosfera contemporánea". In: J. RIECHMANN (coord.). "Ética ecológica: propuestas para una reorientación". Montevideo: Ed. Nordan Comunidad, Col. Ecoteca 33, pp. 217-225.

BATESON, G. (1972). Pasos hacia una ecología de la mente. Una aproximación revolucionaria a la autocomprensión del hombre. Buenos Aires: Ediciones Carlos Lohlé.

BELLO, M. (2013). “Una reflexión en torno a la creación transdicisplinar: el laboratorio como estudio artístico". Conference in Fundación Cerezales Antonino y Cinia within the exhibition "Cabins to Think". 20th- 21st February 2015.

BENNETT, J. (2010). "Political ecologies". Vibrant Matter: A Political Ecology of Things. Durham and London: Duke University Press, pp. 94-109.
B00KCHIN, M. (2005). The Ecology of Freedom. The Emergence and Dissolution of Hierarchy. (2nd ed.) Oakland:AK Press. (1sted. 1982).

BOURRIAUD, N. (2002). Relational Aesthetics. Dijon: Les Presses du Riel. (1st ed. 1998), pp. 11-17.

CARLSON, A. (2009). "Contemporary environmental aesthetics and the requirements of environmentalism". JTLA (Jounal of the Faculty of Letters, The University of Tokyo, Aesthetics). Vol. 34, pp. 1-21.

CASTELLS M. (2009). "Reprogramando las redes de comunicación: movimientos sociales, política insurgente y el nuevo espacio público". Comunicación y Poder. Madrid: Ed. Alianza, pp. 393-533.

CASTELLS, M. (2002). "El reverdecimiento del yo: el movimiento ecologista". La Era de la Información. Vol. II: El Poder de la Identidad. ( $2^{\mathrm{a}}$ ed.). México, Distrito Federal: Siglo XXI Editores, pp. 135-158 (1st. ed. 1998).

DELEUZE, G.; GUATTARI, F. (1994). Capitalismo y esquizofrenia. Vol II: Mil mesetas. (3rd ed.) Valencia: PRE-TEXTOS Ed. (1st ed. 1980).

DEMOS, T. J. (2009). "The Politics of Sustainability: Art and Ecology". Exhibition catalogue: "Radical Nature-Art and Architecture for 


\section{artnodes}

http://artnodes.uoc.edu

a Changing Planet, 1969-2009" (19 Jun-18 0ct/09). London: Barbican Gallery Ed. [Accessed: 24/10/2014]. Pp. 17-3. <http:// sustainabilityparadox.commons.gc.cuny.edu/files/2010/09/ Demos-Politics-of-Sustainability.pdf>

ESCOBAR, A. (1999). "After Nature. Steps on antiessencialist political ecology." Current Antrophology. Vol. 40. Number 1, pp. 1-30 $<$ http://www.unc.edu/ aescobar/html/texts.htm>.

EUROPEAN RESEARCH NETWORK COST ACTION INVESTIGATING CULTURAL SUSTAINABILITY (2015). "Culture(s) in Sustainable Futures: Theories, policies, practices". International Conference Helsinki 6-8 May 2015. <http://www.culturalsustainability.eu/ helsinki2015/About-the-conference $>$ [Accesed: 15th January 2015]

FOUCAULT, M. (2005). Historia de la sexualidad. Vol. I: La Voluntad de Saber. (29th ed.) Paris: Siglo XXI Ed. (1st ed. 1976).

GARCÍA, E. (2004). Medio ambiente y sociedad: La civilización industrial y los límites del planeta. Madrid: Alianza Editorial.

GIOBELLINA, B. L. (2012). "Diagnóstico participativo para la sustentabilidad territorial con enfoque ecofeminista crítico". In: "Innovaciones científicas: la integración de la perspectiva de género". Final confencere of the study: La dimensión de género en los contenidos de la investigación científico-técnica. 29-30 March 2012, Madrid, pp. 1-17 [Accessed: 19/2/2013].

GUATTARI, F. (1996). Las Tres Ecologías. (3rd ed.) Valencia: Ed. PRETEXTOS. (1st ed. 1989).

GUERRA PALMER0, M. J. (2004). "Ecofeminismos: la sostenibilidad de la vida humana como problema". In: J. RIECHMANN, (coord.) "Ética ecológica: propuestas para una reorientación". Montevideo: Ed. Nordan Comunidad, Col. Ecoteca 33, pp. 227-233.

HARAWAY, D. (1991). Simians, Cyborgs and Women: The Reinvention of Nature. New York: Routledge.

IZAGUIRRE, A. (2010). "Teoría estética y ambiente Natural: una aproximación”. Revista Zehar 67, "Paisajes ciegos". Donostia, pp. 16-23

LATOUR, B. (2013). "Políticas de la naturaleza. Por una democracia de las ciencias”. (3a ed.). Barcelona: RBA Libros S.A. (1st ed. 1999).

LETOWSKA, M. (2009). "Things made special - sustainable public art making as collective human behaviour". Glasgow: PAR+RS Feature. <http://www.publicartscotland.com/reflections/17> [Accessed: 5/6/2013]

LÉVI-STRAUSS, C. (2002). El pensamiento salvaje. Madrid: ED. Fondo de Cultura Económica S.L. (1st ed. 1962)
Net-garden: Art, Nature \& Society...

LOZANO, L. (2014). "Biodiversity in the Multifaceted Uncertainty of the Knowledge Economy: the case of ecoLAB". In: [Plastik] Art \& Science, revue du Centre d'études et de recherches en arts plastiques (CERAP) de l'Université de Paris I Panthéon-Sorbonne. NUMÉRO \#04 "Art et biodiversité: un art durable? <http://artscience.univ-paris 1. fr/plastik/document.php?id $=850>$

LUDUEÑA ROMANDINI, F. (2010). La comunidad de los espectros. I. Antropotecnia. Buenos Aires: Miño y Dávila ed.

LUGINBÜHL, Y. (2008). "Representaciones sociales del paisaje y sus evoluciones". In: J. MADERUELO (coord.) (2008) "Paisaje y territorio". Huesca Centro de Arte y Naturaleza de la Fundación Beulas; Madrid: ABADA Editores, pp. 143-180.

MARTÍNEZ RIVILLAS,A. (2012). "Los problemas ambientales: un nuevo llamado a la vita-activa de la filosofía”. Luna Azul. NNo. 35, julio - diciembre 2012. pp. 282-300

MORIN, E. (1998). Sobre la Interdisciplinariedad. Francia: Publicaciones Morinianas. [Accessed: 5/3/2013] <http://www.edgarmorin.org/ publicaciones-morinianas.html>.

PÄCHT, 0. (2011). La Scoperta de la Natura. I primi studi italiani. Torino: Piccola Biblioteca Einaudi 539 Nuova Serie. ( $1^{\text {a }}$ ed.).

REDCLIFT, M.; WOODGATE, G. (1997). Sociología del medio ambiente: una perspectiva internacional. Madrid: Ed. Mc Graw Hill/ Interamericana de España.

ROLSTON, H. (2002). "From Beauty to Duty: Aesthetics of Nature and Environmental Ethics" In: A. BERLEANT (ed). Environment and the Arts: Perspectives on Environmental Aesthetics. Aldershot, Hampshire, UK, and Burlington, VT, pp. 127-141. Chapter 10.

SNYDER, G. (1974). "No Matter, Never Mind". Turtle Island. New York: Ed. New Directions PaperBooks.

STENGERS, I. (2011). "Another science is possible! A plea for slow science". Faculté de Philosophie et Lettres, ULB 13 December 2011, Inauguratial lecture Chair Willy Calewaert 2011-2012 (VUB). [Accessed: 13/02/2014] <http://threerottenpotatoes.files.wordpress.com/2011/06/ stengers2011_pleaslowscience.pdf>

\section{Related links}

$<$ http://laboralcentrodearte.uoc.edu/?cat=3>

$<$ http://econodos.net/ecolab/>

$<$ http://herbarium.cc/> 


\title{
artnodes
}

http://artnodes.uoc.edu

Net-garden: Art, Nature \& Society...

\section{Recommended citation}

LOZANO, Lorena (2015). "Net-garden: Art, Nature \& Society or the Need for a Relational Vision of Organic and Social Life". In: Pau ALSINA and Ana RODRÍGUEZ GRANELL (coord.). "Art Matters". Artnodes. №. 15, pp. 70-80. UOC [Accessed: dd/mm/yy].

$<$ http://journals.uoc.edu/ojs/index.php/artnodes/article/view/n15-Iozano/n15-Iozano-pdf-en> $<$ http://dx.doi.org/10.7238/a.v0i15.2562>

This article is - unless indicated otherwise - covered by the Creative Commons Spain Attribution 3.0 licence. You may copy, distribute, transmit and adapt the work, provided you attribute it (authorship, journal name, publisher) in the manner specified by the author(s) or licensor(s). The full text of the licence can be consulted here: http://creativecommons.org/licenses/by/3.0/es/deed.en.

\section{CV}

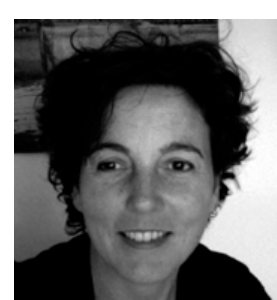

\author{
Lorena Lozano \\ Artist and biologist \\ PhD Program on Economy \& Sociology of Globalisation \\ Oviedo University \\ jardinenred@gmail.com
}

Calle San Juan, $n^{\circ} 16,3^{\circ} \mathrm{D}$

33210, Gijón, Asturias

Lorena Lozano is an artist and a biologist; her research connects art and science, knowledge and methodologies, focusing on the intersection between ecology and new communication technologies. Graduated in Biology (Oviedo University, 1998) and Environmental Art (Glasgow School of Art, Scotland, 2007). She is one of the foundational members and coordinator of ecoLAB, an experimental laboratory on Art, Ecology and Open electronics (Laboral Centro de Arte y Creación Industrial, Gijón 2011-2012). With Rubén Suárez and Javier Palacios, she co-founded the platform econodos_ecology \& communication in 2012. She has been developing the project Herbarium at Fundación Cerezales Antonino y Cinia, León, in the Spanish countryside, since 2013.

\section{$\square$ UOC \\ Universitat Oberta de Catalunya}

